\title{
An integrated approach for the evaluation of technological hazard impacts on air quality: the case of the Val d'Agri oil/gas plant
}

\author{
M. Calvello ${ }^{1,2}$, F. Esposito ${ }^{3}$, and S. Trippetta ${ }^{1,2}$ \\ ${ }^{1}$ IMAA, Istituto di Metodologie per l'Analisi Ambientale, CNR, C.da S. Loja, Z.I., 85050 Tito Scalo (PZ), Italy \\ ${ }^{2}$ Osservatorio Ambientale Val d'Agri, Via Vittorio Emanuele II, 3, 85052 Marsico Nuovo (PZ), Italy \\ ${ }^{3}$ Scuola di Ingegneria, Università degli Studi della Basilicata, Viale dell'Ateneo Lucano 10, 85100 Potenza, Italy \\ Correspondence to: M. Calvello (mariarosaria.calvello@imaa.cnr.it)
}

Received: 27 February 2014 - Published in Nat. Hazards Earth Syst. Sci. Discuss.: 8 April 2014

Revised: 17 June 2014 - Accepted: 22 June 2014 - Published: 21 August 2014

\begin{abstract}
The Val d'Agri area (southern Italy) hosts one of the biggest onshore European reservoir and the largest oil/gas pre-treatment plant, named Centro Olio Val d'Agri (COVA), located in a rural/anthropized context. Several hazards are associated with this plant. These are mainly represented by possible impacts of the COVA atmospheric emissions on the local air quality and human health. This work uses a novel approach based on the integration of air quality measurements from the regional monitoring network, additional experimental measurements (i.e. sub-micrometre particulate matter $\left(\mathrm{PM}_{1}\right)$ and black carbon $\left.(\mathrm{BC})\right)$ and advanced statistical analyses to provide a preliminary evaluation of the Val d'Agri air quality state and give some indication of specific areas potentially affected by COVA hazards. Results show that the COVA plant emissions have a particular impact on the air quality of the area closest to it. In this area several pollutants specifically related to the COVA combustion processes (i.e. nitrogen oxides, benzene and toluene) show the highest concentration values and significant correlations. The proposed approach represents a first step in the assessment of the risks associated with oil/gas exploration and pretreatment activities and a starting point for the development of effective and exportable air quality monitoring strategies.
\end{abstract}

\section{Introduction}

The Val d'Agri area (Basilicata region - southern Italy) is characterized by the peculiar coexistence of natural features (woods and natural parks), large biodiversity, agricultural activities (cultivated and grazing areas) and several small towns alongside anthropogenic activities with potential environmental and health impacts. In fact, the Val d'Agri area houses one of the biggest onshore European reservoir (crude oil and gas) and the largest existing oil/gas pre-treatment plant (identified as Centro Olio Val d'Agri - COVA) in a populated area. In this plant, the fluid extracted from the 25 currently productive wells is transported and separated into three phases: crude oil, natural gas and water. The crude oil is stabilized and conveyed to the Taranto refinery (Puglia region - southern Italy) through a $136 \mathrm{~km}$ long oil pipeline. The natural gas, on the contrary, is treated and delivered to the Italian gas distribution network (Snam Rete Gas S.p.A.). COVA has a nominal treatment capacity of $16500 \mathrm{~m}^{3}$ day $^{-1}$ of crude oil and 3.1 million $\mathrm{sm}^{3}$ day $^{-1}$ of associated gas and represents one of the main sources of atmospheric pollution in the entire area. In fact, the combustion processes occurring in the COVA plant during normal operating conditions originate both gaseous and particulate emissions, giving rise to possible impacts on the local air quality and also posing health risks to the population living close to this plant (Trippetta et al., 2013). Moreover, the activation of emergency operating procedures deriving from plant malfunctions and anomalies represents a further risk for the environment and human health due to additional and possibly enhanced emissions of atmospheric pollutants. Finally, the COVA plant is also classified as subject to considerable risk of industrial injury associated with accidental release of crude oil, methane, propane or other toxic products, or with accidental fires from methane and crude oil (COVA plant External Emergency Plan, which can be found (in Italian) at http://www.osservatoriovaldagri.it/). 
All this implies the need for efficient monitoring of the air quality state in this area, which should be carried out through the implementation of advanced and integrated observing strategies able to characterize and possibly quantify the environmental and human health impacts of such activity. In order to realize effective near-real-time monitoring of environmental hazards associated with the COVA emissions, an advanced network of five stations devoted to the air quality state control has been established in the Val d'Agri area. This network is operated by the Agenzia Regionale per la Protezione dell'Ambiente (ARPA) of the Basilicata region (ARPA Basilicata hereafter) and provides near-realtime concentration measurements of both regulated pollutants (i.e. sulfur dioxide, carbon monoxide, nitrogen dioxide, nitrogen oxides, ozone, particulate matter and benzene) and several pollutants specifically related to oil/gas extraction and treatment activities (i.e. nitrogen monoxide, hydrogen sulfide, methane, non-methane hydrocarbons, total hydrocarbons, toluene, ethylbenzene and isomers of xylene). To the best of our knowledge, this is the first air quality network which provides continuous concentration measurements of so many pollutants in a such small area, even when compared, for example to the very efficient observing network operating near the five refineries in the San Francisco Bay Area described in a recent comprehensive report by Fujita and Campbell (2013). More common monitoring strategies are mainly devoted to the study of volatile organic compounds (VOCs) and sulfur dioxide near refineries (Baltrènas et al., 2011; Lin et al., 2008) or near industrial parks, including petrochemical facilities (Liu et al., 2008; Hsieh et al., 2006). Nevertheless, more investigation should be done. In fact, previous studies carried out in the Val d'Agri area suggested the need for the integration of the existing observations with experimental measurements of sub-micrometre aerosol particles (i.e. $\mathrm{PM}_{1}$, aerosol particles with an aerodynamic diameter less than $1.0 \mu \mathrm{m}$ ) and black carbon (BC hereafter) due to their possible association with combustion processes such as those occurring in the COVA plant (Trippetta et al., 2013; Pavese et al., 2012). The importance of the measurement of $\mathrm{PM}_{1}$ and $\mathrm{BC}$ is especially related to their adverse effects on environment and human health (e.g. Mohiuddin et al., 2014; Anenberg et al., 2011). Moreover, BC also contributes significantly to global warming (Bond et al., 2013). Despite this, there is still a relatively limited amount of data for the sub-micrometre atmospheric particle fraction available at present (Mirante et al., 2013), and only recently there has been growth for $\mathrm{BC}$ monitoring networks in many countries around the world; these networks often employ Aethalometers due to their good time resolution, portability and low costs (see, for example, the US EPA network in Solomon et al. (2008), the UK Black Carbon Network in Butterfield et al. (2010) and the Swiss National Air Pollution Monitoring Network - NABEL in EMPA (2010)).

The present study enters into this context, and its main goal is to provide a preliminary evaluation of the air qual- ity state of the Val d'Agri area and to give some indication of specific areas potentially affected by hazards deriving from the COVA plant through the use of a novel approach based on the integration of routine air quality measurements, additional experimental measurements and advanced statistical analyses.

To this aim, as a preliminary phase, daily concentrations of the main pollutants measured at the five monitoring stations located in the Val d'Agri area in the period 1 September31 October 2013 were considered and analysed along with simultaneous concentration measurements of $\mathrm{PM}_{1}$ and $\mathrm{BC}$ obtained at two of the five sampling sites and involving additional experimental facilities by the Istituto di Metodologie per l'Analisi Ambientale (IMAA) of the National Research Council of Italy (CNR). In particular, the temporal and spatial variability of the pollutant concentration measurements and the relative correlations were investigated using multivariate statistical techniques, which also provided a preliminary indication of the source types contributing to their presence in the local atmosphere.

The possibility to integrate measurements from the existing monitoring network with further key parameters as $\mathrm{PM}_{1}$ and $\mathrm{BC}$ with an in-depth cluster and spatial variance analyses represents a powerful approach to study the COVA influence on the Val d'Agri environment. This will provide useful indications to the stakeholders in order to develop better emission control strategies and to reach a sustainable equilibrium between the environmental impact of energy supply by oil/gas resources and the strong agricultural vocation of the area and to improve the standards of living for the Val d'Agri population.

\section{Materials and methodologies}

\subsection{The ARPA Basilicata air quality monitoring network}

The Val d'Agri air quality monitoring network consists of five monitoring stations: Viggiano Zona Industriale (VZI; $40^{\circ} 18^{\prime} 50.64^{\prime \prime} \mathrm{N}, 15^{\circ} 54^{\prime} 16.69^{\prime \prime} \mathrm{E}$ ), Viggiano 1 (V1; $\left.40^{\circ} 20^{\prime} 4.58^{\prime \prime} \mathrm{N}, 15^{\circ} 54^{\prime} 1.90^{\prime \prime} \mathrm{E}\right)$, Masseria De Blasiis (MDB; $40^{\circ} 19^{\prime} 26.18^{\prime \prime} \mathrm{N}, 15^{\circ} 52^{\prime} 2.58^{\prime \prime} \mathrm{E}$ ), Grumento Nova $\left(\mathrm{GN} ; 40^{\circ} 17^{\prime} 18.00^{\prime \prime} \mathrm{N}, 15^{\circ} 53^{\prime} 28.00^{\prime \prime} \mathrm{E}\right)$ and Costa Molina Sud 1 (CMS; $\left.40^{\circ} 18^{\prime} 57.00^{\prime \prime} \mathrm{N}, 15^{\circ} 57^{\prime} 15.00^{\prime \prime} \mathrm{E}\right)$. The monitoring stations are located at a distance ranging between about $500 \mathrm{~m}$ and about $4800 \mathrm{~m}$ from the COVA plant and are representative of the air quality of an area of about $100 \mathrm{~km}^{2}$ around this plant (Fig. 1).

All the stations provide continuous and near-real-time measurements of the concentrations of sulfur dioxide $\left(\mathrm{SO}_{2}\right)$, carbon monoxide (CO), nitrogen monoxide and dioxide (NO and $\mathrm{NO}_{2}$, respectively), nitrogen oxides $\left(\mathrm{NO}_{\mathrm{x}}\right.$, which is the sum of $\mathrm{NO}$ and $\left.\mathrm{NO}_{2}\right)$, ozone $\left(\mathrm{O}_{3}\right)$, hydrogen sulfide $\left(\mathrm{H}_{2} \mathrm{~S}\right)$, methane $\left(\mathrm{CH}_{4}\right)$, non-methane hydrocarbons (NMHCs), total 


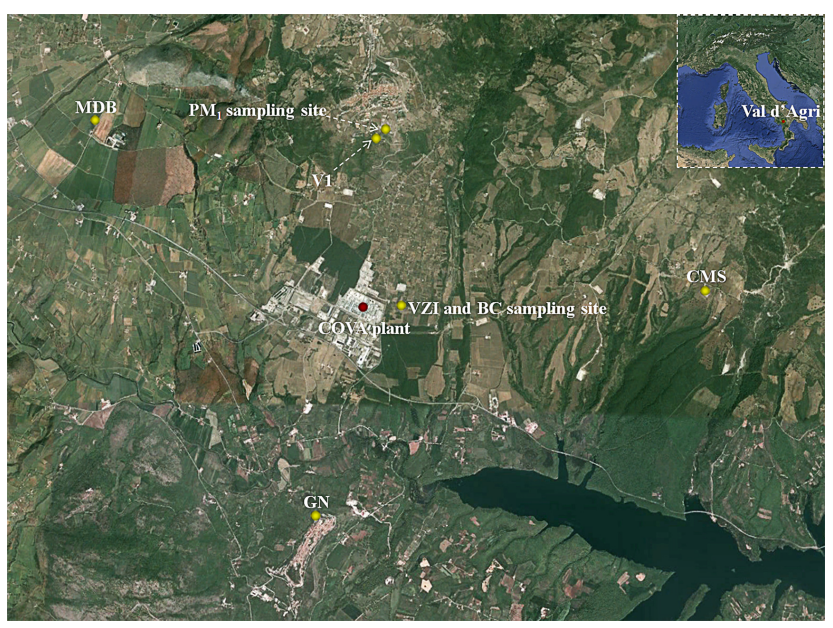

Figure 1. Location of the five stations of the ARPA Basilicata air quality monitoring network. The image also shows the location of the $\mathrm{PM}_{1}$ and $\mathrm{BC}$ sampling sites and of the Centro Olio Val d'Agri (COVA) plant. Aerial photography courtesy of Google Earth (http://earth.google.com/). Legend: Viggiano Zona Industriale (VZI), Viggiano 1 (V1), Masseria De Blasiis (MDB), Grumento Nova (GN) and Costa Molina Sud 1 (CMS).

hydrocarbons (THC; i.e. the sum of $\mathrm{CH}_{4}$ and NMHCs), benzene $\left(\mathrm{C}_{6} \mathrm{H}_{6}\right)$, toluene, ethylbenzene and isomers of xylene. Moreover, V1, MDB, GN and CMS also provide continuous and near-real-time measurements of the concentrations of particulate matter with an aerodynamic diameter less than 10 and $2.5 \mu \mathrm{m}\left(\mathrm{PM}_{10}\right.$ and $\mathrm{PM}_{2.5}$, respectively). Regarding VZI, it is equipped for the measurement of the $\mathrm{PM}_{10}$ concentrations only. These measurements are provided with a time lag of several months due to the instrumentation used (i.e. a gravimetric sampler). A summary of the methods used for the measurements of the concentrations of each pollutant is reported in Table 1.

All the air quality monitoring stations also provide measurements of the main meteorological parameters: air temperature $(T)$, atmospheric pressure $(P)$, relative humidity $(\mathrm{RH})$, wind speed (ws) and direction (wd), global radiation (GR) and rainfall (rf).

\subsection{Experimental $\mathrm{PM}_{1}$ and $\mathrm{BC}$ measurements}

$\mathrm{PM}_{1}$ measurements were performed in Viggiano at a distance of about $170 \mathrm{~m}$ (SW direction) from V1-ARPA Basilicata monitoring station (Fig. 1). This site was chosen since Viggiano is the nearest town to the COVA plant, at about $2400 \mathrm{~m}$ from it, and one of the most populated towns of the Val d'Agri area (about 3100 inhabitants). PM $_{1}$ samples were collected using a low-volume $\left(16.7 \mathrm{~L} \mathrm{~min}^{-1}\right.$ flow rate) gravimetric sampler (TCR Tecora) equipped with a $\mathrm{PM}_{1}$ cutoff inlet and polycarbonate filters $(\varnothing=47 \mathrm{~mm})$. The sampling time was $24 \mathrm{~h}$ (starting from $12.00 \mathrm{pm}$ ), and each filter was humidity-conditioned in a filter-conditioning cabi- net (approximately $T=20 \pm 2{ }^{\circ} \mathrm{C}$ and $\mathrm{RH}=50 \pm 5 \%$ ) before and after sampling for $48 \mathrm{~h}$. The $\mathrm{PM}_{1}$ mass was determined by means of a gravimetric method using an analytical microbalance with a sensitivity of $\pm 1 \mu \mathrm{g}$.

Regarding BC measurements, they were performed close to the COVA plant by placing a dedicated instrument at VZI-ARPA Basilicata monitoring station. This location was chosen for its closeness to the COVA, where continuous combustion processes were thought to have an impact on BC content. A rack-mount seven-wavelengths Magee Scientific Aethalometer AE31 (370, 470, 520, 590, 660, 880 and $950 \mathrm{~nm}$ ) was used to estimate $\mathrm{BC}$ mass concentrations and to detect the presence of its organic fraction through the UV-absorbing particulate matter (UVPM) quantity. The Aethalometer measures light attenuation due to the presence of absorbing carbonaceous aerosol deposits on a quartz fibre filter (Hansen, 2005). Corresponding absorption coefficients are obtained at the seven wavelengths and converted to mass concentrations with, in particular, measurements at the $880 \mathrm{~nm}$ wavelength used to obtain BC content assuming a mass-specific absorption cross section of $16.6 \mathrm{~m}^{2} \mathrm{~g}^{-1}$ (Nair et al., 2012; Reche et al., 2011). If the organic component is present in carbonaceous aerosols, an enhanced absorption at the UV wavelengths is recorded, leading to qualitative detection of this component through measurements at $370 \mathrm{~nm}$ (Esposito et al., 2012). For the data considered in this work, the instrument was equipped with a cut size-selective cyclone to intake particles with aerodynamic diameters less than $2.5 \mu \mathrm{m}$ at a flow rate of $4 \mathrm{~L} \mathrm{~min}^{-1}$ and a time resolution of $5 \mathrm{~min}$.

\subsection{Meteorology and air mass history}

A summary of the main meteorological parameters averaged over the period 1 September-31 October 2013 is reported in Table 2 for the five monitoring stations.

Low variations were observed for all parameters showing a quite homogeneous meteorological pattern all over the study area. Looking at the prevailing wind directions, westerly winds were more frequent for all the sites except for VZI monitoring station where a southeastern component was present. During the study period, the area was affected by frequent anticyclonic systems, as verified by the map of the $850 \mathrm{hPa}$ geopotential heights obtained from the NOAA-NCEP/NCAR (National Oceanic and Atmospheric Administration-National Centers for Environmental Prediction/National Center for Atmospheric Research) global reanalysis database (http://www.esrl.noaa.gov/psd/ data/gridded/data.ncep.reanalysis.derived.html; Kalnay et al., 1996) (Fig. 2).

The same database was used to initialize HYSPLIT (HYbrid Single-Particle Lagrangian Integrated Trajectory; Draxler and Rolph, 2003) model cluster analysis of backward trajectories in order to assess the main air mass transport patterns affecting the study area from 1 September to 31 October. In particular, five-day backward trajectories arriving 
Table 1. Summary of the methods used for measuring concentrations of each pollutant.

\begin{tabular}{ll}
\hline Parameter & Measurement principle \\
\hline $\mathrm{SO}_{2}$ & UV fluorescence \\
$\mathrm{NO}$ & Chemiluminescence \\
$\mathrm{NO}_{2}$ & Chemiluminescence \\
$\mathrm{NO}_{\mathrm{x}}$ & Chemiluminescence \\
$\mathrm{PM}_{2.5}$ & Beta attenuation* \\
$\mathrm{PM}_{10}$ & Beta attenuation*/gravimetric** \\
$\mathrm{O}_{3}$ & UV absorption \\
$\mathrm{CO}$ & Non-dispersive IR detection (NDIR) \\
$\mathrm{C}_{6} \mathrm{H}_{6}$ & Gas chromatography with photo-ionization detector (GC-PID) \\
$\mathrm{H}_{2} \mathrm{~S}$ & UV fluorescence \\
$\mathrm{CH}$ & Photo-ionization detection (PID) \\
$\mathrm{NMHCs}_{\mathrm{THC}}$ & Photo-ionization detection (PID) \\
$\mathrm{Toluene}_{\text {Ethylbenzene }}$ & Photo-ionization detection (PID) \\
Isomers of xylene & Gas chromatography with photo-ionization detector (GC-PID) \\
\hline v1, GN, MDB and CMS & monitoring stations; ** vZI monitoring station.
\end{tabular}

Table 2. Mean \pm standard deviation $(m \pm$ SD) of the main meteorological parameters measured at the five air quality monitoring stations from 1 September to 31 October 2013. Regarding the wind direction (wd), the prevailing directions evaluated for the entire period of observation are reported.

\begin{tabular}{lrrrrlrr}
\hline $\begin{array}{l}\text { Monitoring } \\
\text { station }\end{array}$ & $\begin{array}{r}T \\
\left({ }^{\circ} \mathrm{C}\right)\end{array}$ & $\begin{array}{r}\text { RH } \\
(\%)\end{array}$ & $\begin{array}{r}P \\
(\mathrm{hPa})\end{array}$ & $\begin{array}{r}\text { ws } \\
\left(\mathrm{ms}^{-1}\right)\end{array}$ & Prevailing wd & $\begin{array}{r}\text { GR } \\
\left(\mathrm{Wm}^{-2}\right)\end{array}$ & $\begin{array}{r}\text { rf } \\
(\mathrm{mm})\end{array}$ \\
\hline VZI & $17 \pm 3$ & $74 \pm 9$ & $946 \pm 4$ & $1.2 \pm 0.5$ & SE/SW & $174 \pm 59$ & $1.8 \pm 3.9$ \\
V1 & $17 \pm 2$ & $66 \pm 11$ & $933 \pm 4$ & $3.4 \pm 1.6$ & SW/NW & $159 \pm 55$ & $1.4 \pm 4.3$ \\
MDB & $16 \pm 3$ & $75 \pm 8$ & $948 \pm 4$ & $3.1 \pm 1.6$ & NW & $149 \pm 47$ & $1.1 \pm 3.5$ \\
GN & $17 \pm 3$ & $64 \pm 11$ & $932 \pm 4$ & $2.4 \pm 1.3$ & SW & $106 \pm 42$ & $0.1 \pm 0.6$ \\
CMS & $18 \pm 3$ & $73 \pm 11$ & $939 \pm 4$ & $3.7 \pm 1.7$ & NW & $167 \pm 58$ & $1.3 \pm 3.8$ \\
\hline
\end{tabular}

at $500 \mathrm{~m}$ above ground level (a.g.1.) were computed 4 times daily and further put together in different clusters according to similar transport patterns. A map with the mean trajectory for each representative cluster and the corresponding percentage of occurrence is shown in Fig. 3. As Fig. 3 shows, $48 \%$ of the total backward trajectories travelled very low before reaching the study area, and among these, $45 \%$ were of local origin remaining over the Tirrenian Sea. This could have favoured the accumulation of pollutants in the lowest atmospheric layers during the study period.

\section{Results and discussion}

\subsection{Explorative statistical analysis}

Table 3 reports a summary of the explorative statistical analysis carried out on the pollutant mean daily concentrations measured in the area under study from 1 September to 31 October 2013. Concentration measurements of ethylbenzene and isomers of xylene were not considered in this study due to the several data being missing. As Table 3 shows, significantly higher values of $\mathrm{NO}, \mathrm{NO}_{2}, \mathrm{NO}_{\mathrm{x}}, \mathrm{C}_{6} \mathrm{H}_{6}$ and toluene daily concentrations were registered at VZI monitoring station with respect to the other four stations. These compounds mainly originate from anthropogenic sources, including the COVA plant. In fact, $\mathrm{NO}_{\mathrm{x}}$ and VOCs represent some of the main gaseous emissions of this plant (ENI, 2012). Therefore, the higher concentration values recorded at VZI monitoring station should be also related to a contribution from COVA to their presence in the local atmosphere. Furthermore, $\mathrm{CH}_{4}$ daily concentrations showed higher values at MDB monitoring station, likely due to its proximity to several farms devoted to the breeding of dairy cows. In fact, the livestock sector is one of the largest contributors to greenhouse gas emissions globally, mostly as $\mathrm{CH}_{4}$ emissions (Van Middelaar et al., 2014; Liang et al., 2013). Finally, higher $\mathrm{H}_{2} \mathrm{~S}$ concentration values were registered at CMS station.

Figure 4 reports the temporal pattern of the $\mathrm{PM}_{1}$ daily concentrations. As Fig. 4 shows, the $\mathrm{PM}_{1}$ daily concentrations ranged from 1.1 to $7.4 \mu \mathrm{g} \mathrm{m}^{-3}$, with a mean value of $2.7 \mu \mathrm{g} \mathrm{m}^{-3}$. Due to the lack of $\mathrm{PM}_{1}$ measurements performed 
Table 3. Statistical parameters of the atmospheric pollutant daily concentrations measured at the five air quality monitoring stations from 1 September to 31 October 2013. Mean \pm standard deviation $(m \pm$ SD) and the range of variability (min-max) are reported for each pollutant. Legend: n.a. = not available; m.u. = measurement units.

\begin{tabular}{|c|c|c|c|c|c|c|}
\hline \multirow{2}{*}{ Parameter } & \multirow{2}{*}{ m.u. } & \multicolumn{5}{|c|}{ ARPA Basilicata monitoring stations } \\
\hline & & VZI & V1 & MDB & GN & CMS \\
\hline $\mathrm{SO}_{2}$ & $\mu \mathrm{g} \mathrm{m}^{-3}$ & $\begin{array}{r}5.61 \pm 1.88 \\
(3.31-12.39)\end{array}$ & $\begin{array}{r}6.74 \pm 0.77 \\
(5.34-10.68)\end{array}$ & $\begin{array}{l}7.56 \pm 1.08 \\
(5.07-9.83)\end{array}$ & $\begin{array}{l}3.69 \pm 1.00 \\
(1.91-6.85)\end{array}$ & $\begin{array}{l}3.41 \pm 1.30 \\
(1.31-7.13)\end{array}$ \\
\hline NO & $\mu \mathrm{g} \mathrm{m}^{-3}$ & $\begin{array}{l}5.05 \pm 1.83 \\
(2.34-8.42)\end{array}$ & $\begin{array}{l}1.03 \pm 0.44 \\
(0.12-2.48)\end{array}$ & $\begin{array}{l}1.31 \pm 0.64 \\
(0.38-3.38)\end{array}$ & $\begin{array}{l}0.98 \pm 0.48 \\
(0.18-2.60)\end{array}$ & $\begin{array}{l}0.73 \pm 0.40 \\
(0.16-1.66)\end{array}$ \\
\hline $\mathrm{NO}_{2}$ & $\mu \mathrm{g} \mathrm{m}^{-3}$ & $\begin{array}{l}12.63 \pm 4.30 \\
(6.45-25.26)\end{array}$ & $\begin{array}{r}4.36 \pm 1.96 \\
(1.09-13.32)\end{array}$ & $\begin{array}{l}4.89 \pm 1.34 \\
(2.62-7.95)\end{array}$ & $\begin{array}{l}3.62 \pm 1.54 \\
(0.44-7.03)\end{array}$ & $\begin{array}{l}3.49 \pm 1.30 \\
(0.46-7.25)\end{array}$ \\
\hline $\mathrm{NO}_{\mathrm{x}}$ & $\mu \mathrm{g} \mathrm{m}{ }^{-3}$ & $\begin{array}{l}20.35 \pm 6.63 \\
(9.95-37.96)\end{array}$ & $\begin{array}{r}5.94 \pm 2.36 \\
(2.21-17.12)\end{array}$ & $\begin{array}{r}6.89 \pm 1.98 \\
(3.21-11.84)\end{array}$ & $\begin{array}{l}5.13 \pm 2.05 \\
(1.22-9.33)\end{array}$ & $\begin{array}{l}4.60 \pm 1.75 \\
(0.85-9.19)\end{array}$ \\
\hline $\mathrm{PM}_{10}$ & $\mu g \mathrm{~m}^{-3}$ & n.a. & $\begin{array}{l}16.09 \pm 6.35 \\
(6.12-36.63)\end{array}$ & $\begin{array}{r}20.97 \pm 7.21 \\
(11.50-39.40)\end{array}$ & $\begin{array}{l}15.25 \pm 5.16 \\
(5.80-25.80)\end{array}$ & $\begin{array}{l}18.31 \pm 5.68 \\
(8.91-36.00)\end{array}$ \\
\hline $\mathrm{PM}_{2.5}$ & $\mu \mathrm{g} \mathrm{m}^{-3}$ & n.a. & $\begin{array}{r}8.99 \pm 4.03 \\
(3.30-22.20)\end{array}$ & $\begin{array}{l}11.69 \pm 4.59 \\
(3.80-21.90)\end{array}$ & $\begin{array}{r}8.74 \pm 3.73 \\
(2.90-16.40)\end{array}$ & $\begin{array}{r}8.63 \pm 3.94 \\
(2.50-18.80)\end{array}$ \\
\hline $\mathrm{O}_{3}$ & $\mu \mathrm{g} \mathrm{m}{ }^{-3}$ & $\begin{array}{l}58.68 \pm 14.32 \\
(25.96-90.34)\end{array}$ & $\begin{array}{r}82.73 \pm 13.72 \\
(50.28-116.38) \\
\end{array}$ & $\begin{array}{l}48.76 \pm 14.76 \\
(18.24-81.21)\end{array}$ & $\begin{array}{r}85.32 \pm 15.48 \\
(47.07-124.72)\end{array}$ & $\begin{array}{r}69.99 \pm 14.57 \\
(37.57-104.31) \\
\end{array}$ \\
\hline $\mathrm{CO}$ & $\mu \mathrm{g} \mathrm{m}^{-3}$ & $\begin{array}{l}0.34 \pm 0.11 \\
(0.17-0.58)\end{array}$ & $\begin{array}{l}0.17 \pm 0.05 \\
(0.05-0.40)\end{array}$ & $\begin{array}{l}0.15 \pm 0.03 \\
(0.10-0.22)\end{array}$ & $\begin{array}{l}0.33 \pm 0.08 \\
(0.11-0.60)\end{array}$ & $\begin{array}{l}0.22 \pm 0.05 \\
(0.09-0.30)\end{array}$ \\
\hline $\mathrm{C}_{6} \mathrm{H}_{6}$ & $\mu \mathrm{g} \mathrm{m}^{-3}$ & $\begin{array}{l}0.91 \pm 0.16 \\
(0.63-1.44)\end{array}$ & $\begin{array}{l}0.30 \pm 0.11 \\
(0.12-0.52)\end{array}$ & $\begin{array}{l}0.28 \pm 0.11 \\
(0.08-0.60)\end{array}$ & $\begin{array}{l}0.17 \pm 0.10 \\
(0.03-0.49)\end{array}$ & $\begin{array}{l}0.22 \pm 0.07 \\
(0.10-0.39)\end{array}$ \\
\hline Toluene & $\mu \mathrm{g} \mathrm{m}^{-3}$ & $\begin{array}{l}1.01 \pm 0.38 \\
(0.50-2.27)\end{array}$ & $\begin{array}{l}0.43 \pm 0.19 \\
(0.12-0.97)\end{array}$ & $\begin{array}{l}0.34 \pm 0.15 \\
(0.13-0.81)\end{array}$ & $\begin{array}{l}0.19 \pm 0.10 \\
(0.05-0.43)\end{array}$ & $\begin{array}{l}0.24 \pm 0.08 \\
(0.12-0.43)\end{array}$ \\
\hline $\mathrm{CH}_{4}$ & $\mu \mathrm{Cg} \mathrm{m}{ }^{-3}$ & $\begin{array}{l}958.03 \pm 34.99 \\
(887.0-1038.0)\end{array}$ & $\begin{array}{r}902.69 \pm 16.75 \\
(874.0-946.0)\end{array}$ & $\begin{array}{r}1114.94 \pm 95.97 \\
(972.00-1609.00)\end{array}$ & $\begin{array}{r}944.44 \pm 33.21 \\
(814.00-1005.00)\end{array}$ & $\begin{array}{r}911.92 \pm 26.57 \\
(856.00-978.00)\end{array}$ \\
\hline $\mathrm{NMHCs}$ & $\mu \mathrm{Cg} \mathrm{m}{ }^{-3}$ & $\begin{array}{r}103.26 \pm 108.59 \\
(27.75-563.58)\end{array}$ & $\begin{array}{l}24.08 \pm 9.08 \\
(4.04-44.69)\end{array}$ & $\begin{array}{r}103.02 \pm 81.56 \\
(0.89-342.68)\end{array}$ & $\begin{array}{r}146.05 \pm 10.85 \\
(121.75-164.59)\end{array}$ & $\begin{array}{l}65.08 \pm 23.81 \\
(4.87-111.84)\end{array}$ \\
\hline THC & $\mu \mathrm{Cg} \mathrm{m}-3$ & $\begin{array}{r}1060.97 \pm 90.91 \\
(979.16-1455.15)\end{array}$ & $\begin{array}{r}926.81 \pm 23.03 \\
(881.84-980.90)\end{array}$ & $\begin{array}{r}1217.50 \pm 116.53 \\
(1065.88-1949.11) \\
\end{array}$ & $\begin{array}{r}1094.41 \pm 39.38 \\
(959.69-1169.32)\end{array}$ & $\begin{array}{r}976.84 \pm 21.93 \\
(934.32-1018.41) \\
\end{array}$ \\
\hline $\mathrm{H}_{2} \mathrm{~S}$ & $\mu \mathrm{g} \mathrm{m}^{-3}$ & $\begin{array}{l}1.87 \pm 0.37 \\
(0.99-2.71)\end{array}$ & $\begin{array}{l}1.80 \pm 0.43 \\
(1.02-2.79)\end{array}$ & $\begin{array}{l}0.56 \pm 0.36 \\
(0.10-2.14)\end{array}$ & $\begin{array}{l}1.59 \pm 0.50 \\
(0.50-3.14)\end{array}$ & $\begin{array}{l}2.72 \pm 0.47 \\
(1.07-3.74)\end{array}$ \\
\hline
\end{tabular}

in the area under study during the considered period, these values were compared with the unique $\mathrm{PM}_{1}$ concentration measurements presently existing for this area and reported in a previous study (Trippetta et al., 2013). Results show that the $\mathrm{PM}_{1}$ daily concentrations registered during the period under consideration were lower than the $\mathrm{PM}_{1}$ concentration mean value $\left(11.0 \pm 5.1 \mathrm{~g} \mathrm{~m} \mathrm{~m}^{-3}\right)$ measured close to the COVA plant from July to November 2011.

Daily values of BC and UVPM content are reported in Fig. 5. BC daily concentrations were found in the range from 288 to $1125 \mathrm{ng} \mathrm{m}^{-3}$ with a mean value of $551 \mathrm{ng} \mathrm{m}^{-3}$. Also, in the case of $\mathrm{BC}$, a comparison was possible with the unique data set of $\mathrm{BC}$ concentration measurements available for the area described in Pavese et al. (2012). In that case, a slightly lower monthly mean value of $494 \mathrm{ng} \mathrm{m}^{-3}$ was obtained in February 2011, while higher mean monthly values of 822 , 735 and $858 \mathrm{ng} \mathrm{m}^{-3}$ were found in January, March and April 2011, respectively.

For UVPM, estimated values were included in the range from 2 to $267 \mathrm{ng} \mathrm{m}^{-3}$ with a mean value of $84 \mathrm{ng} \mathrm{m}^{-3}$, implying the constant presence of the organic component of carbonaceous particles during the sampling period.

\subsection{Cluster analysis}

In order to study the correlation pattern between the pollutant concentration data registered at each site, and to obtain 


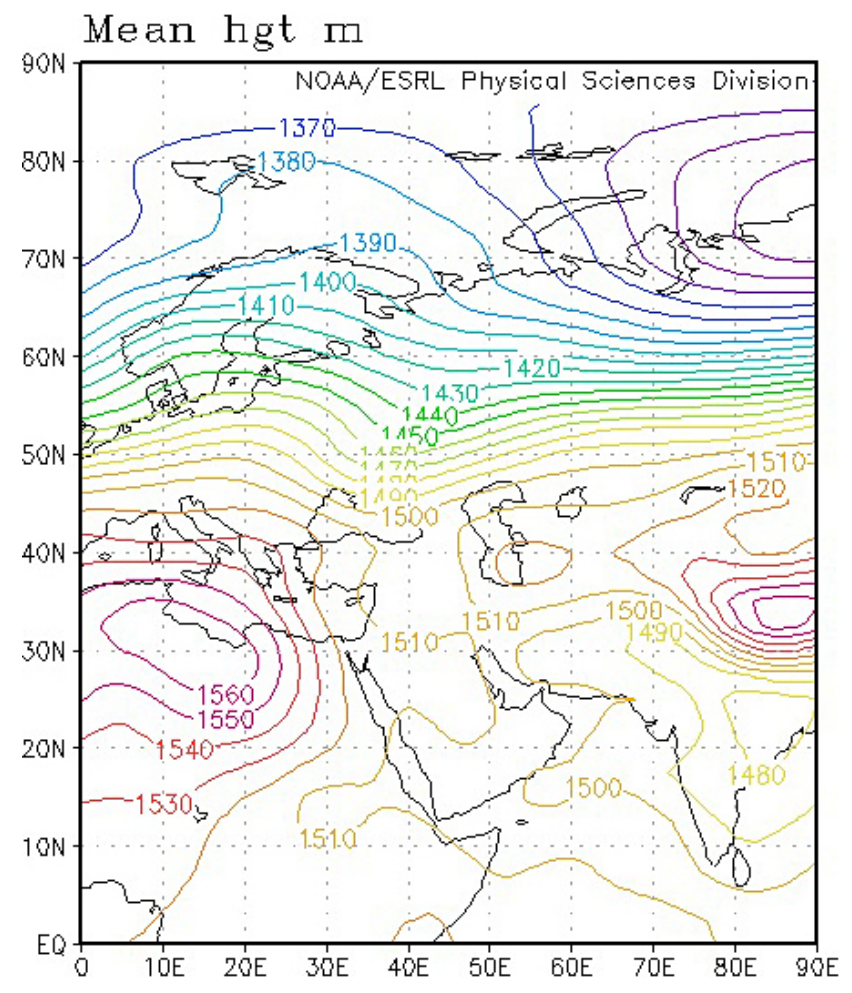

Figure 2. Map of the $850 \mathrm{hPa}$ geopotential heights averaged for the period 1 September-31 October 2013 from the NOAANCEP/NCAR (National Oceanic and Atmospheric AdministrationNational Centers for Environmental Prediction/National Center for Atmospheric Research) reanalysis database.

a preliminary indication of the source types contributing to their presence in the local atmosphere, cluster analysis (CA) was used. In particular, a hierarchical-type clustering algorithm was applied to the Pearson correlation $(\rho)$ matrix, and the furthest-neighbour method was chosen as a criterion for forming clusters (Legendre and Legendre, 1985).

For this analysis, THC was considered as the sum of $\mathrm{CH}_{4}$ and $\mathrm{NMHCs}$, and $\mathrm{NO}_{\mathrm{x}}$ as the sum of $\mathrm{NO}$ and $\mathrm{NO}_{2}$, in order to avoid redundant information.

By applying CA to the pollutant concentration data recorded at VZI monitoring site, three clusters and three isolated variables were found (Fig. 6a). In particular, the first cluster is composed of $\mathrm{C}_{6} \mathrm{H}_{6}$ and toluene; the second includes $\mathrm{SO}_{2}$ and $\mathrm{NO}_{\mathrm{x}}$; and the third consists of $\mathrm{BC}$, UVPM and THC. $\mathrm{CO}, \mathrm{H}_{2} \mathrm{~S}$ and $\mathrm{O}_{3}$ represent the isolated variables. By analysing each identified cluster, it can be observed that $\mathrm{C}_{6} \mathrm{H}_{6}$ and toluene, which belong to the aromatic VOCs group, show a good correlation $(\rho=0.86)$. This could suggest a common source of these two compounds in the considered area. Major sources of ambient VOCs - especially of benzene, toluene, ethylbenzene and isomers of xylene (BTEX) - include vehicular emissions, automobile service stations and industrial emissions (Caselli et al., 2010). In particular, the vehicular emissions come from different

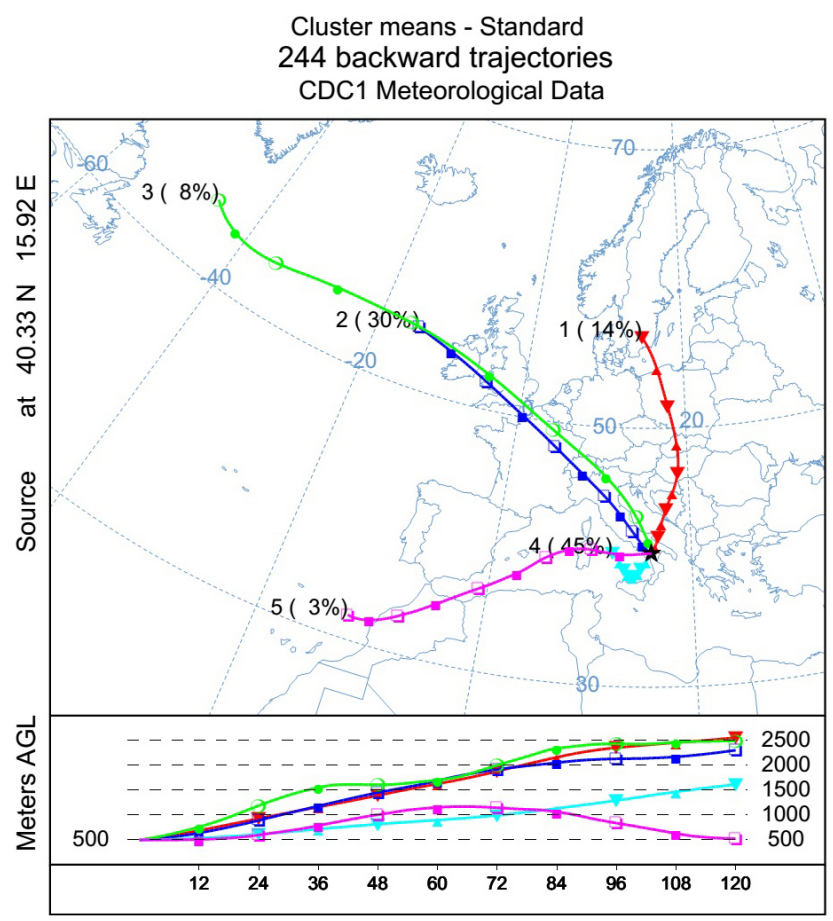

Figure 3. Maps with average trajectories for each obtained cluster and corresponding percentage of occurrence (in brackets) for the period 1 September-31 October 2013. The numbers outside the brackets identify each cluster.

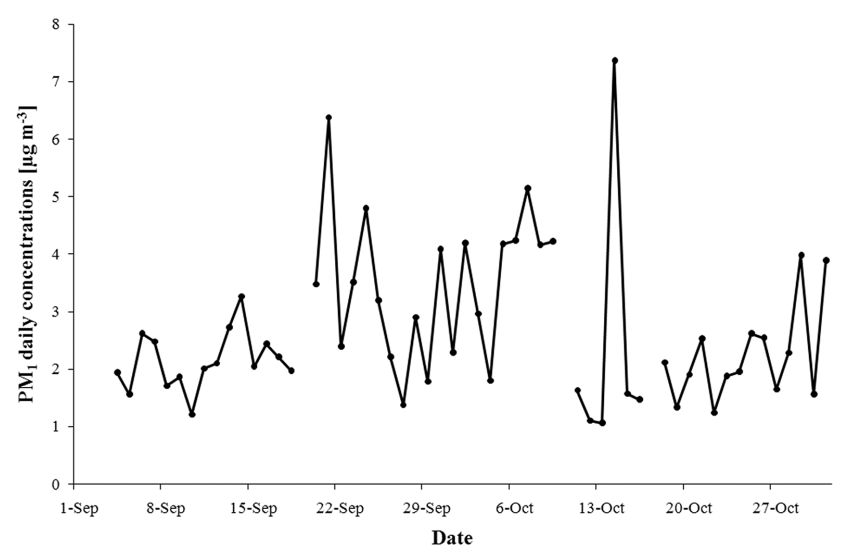

Figure 4. Temporal pattern of the $\mathrm{PM}_{1}$ daily concentrations measured at Viggiano town from 1 September to 31 October 2013.

sources: exhaust emissions (cold and hot), evaporative emissions, and emissions from brake and tyre wear. Among the BTEX industrial emissions, those related to petroleum production processes represent an important source of these compounds (Godoi et al., 2013). Therefore, the presence of $\mathrm{C}_{6} \mathrm{H}_{6}$ and toluene in the local atmosphere of the Viggiano industrial area could be due to the contribution of both traffic and COVA emissions. Focusing on the second cluster, $\mathrm{SO}_{2}$ and $\mathrm{NO}_{\mathrm{x}}$ show a significant correlation $(\rho=0.69)$. These two 


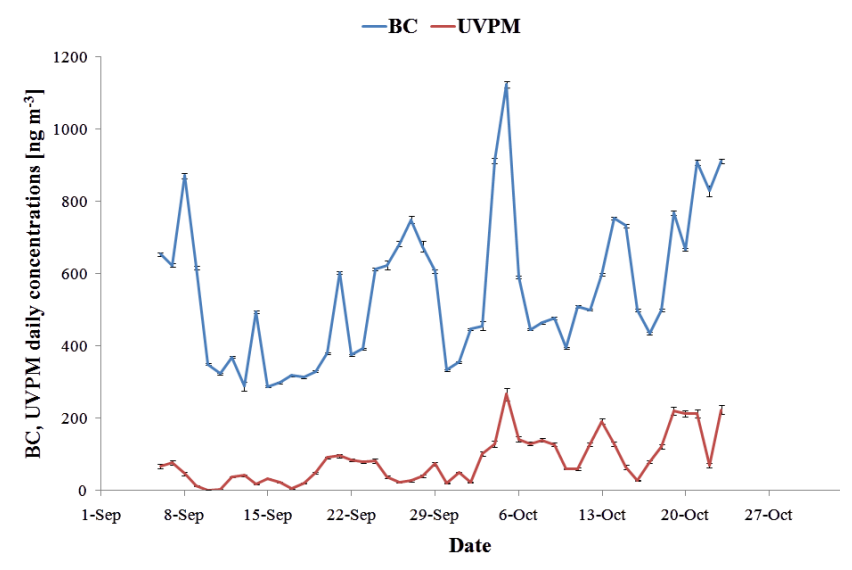

Figure 5. Temporal patterns of daily values of black carbon (BC) and UV-absorbing particulate matter (UVPM) content obtained at Viggiano Zona Industriale (VZI) station from 6 September to 23 October 2013.

gaseous compounds represent the main gases emitted by the COVA thermodestroyers (ENI, 2012). Therefore, the significant $\mathrm{SO}_{2}$ and $\mathrm{NO}_{\mathrm{x}}$ correlation could suggest the influence of the COVA emissions on the local air quality. Regarding the third cluster, a good correlation is found between BC and UVPM $(\rho=0.53)$ as well as between these two parameters and THC $(\rho=0.45)$. The formation of this cluster can be explained by incomplete combustion processes as a common source of all the three parameters, and highlights the strong interaction between the particle phase represented by $\mathrm{BC}$ and the organic molecular species contained in UVPM. These molecules, quantitatively determined by THC concentration measurements, are verified to have a high probability to be adsorbed on BC particles surfaces (Kim et al., 2009). From concentration values in Table 3 , it can be easily verified that more than $90 \%$ of THC consists of methane, and therefore a good correlation between $\mathrm{BC}, \mathrm{UVPM}$ and $\mathrm{CH}_{4}$ can be inferred from CA. Since the presence of methane in the local atmosphere of the area covered by VZI monitoring station is very likely related to COVA combustion processes, rather than traffic, the same prevailing source can be attributed to $\mathrm{BC}$ and UVPM emissions at the sampling site under consideration.

By considering V1 monitoring site, the application of CA to the pollutant daily concentration data pointed out three clusters and four isolated variables (Fig. 6b). Since the $\mathrm{PM}_{1}$ monitoring site is very close to $\mathrm{V} 1$ monitoring station, it can be assumed that these two sites are representative of the same area, implying that $\mathrm{PM}_{1}$ measurements can be considered along with those performed at V1 monitoring station in CA. As Fig. 6b shows, the first cluster includes $\mathrm{PM}_{10}$ and $\mathrm{PM}_{2.5}$; the second is composed of $\mathrm{NO}_{\mathrm{x}}, \mathrm{C}_{6} \mathrm{H}_{6}$ and toluene; and the third consists of $\mathrm{CO}$ and THC. $\mathrm{H}_{2} \mathrm{~S}, \mathrm{O}_{3}, \mathrm{PM}_{1}$ and $\mathrm{SO}_{2}$ represent the isolated variables. Focusing on each single cluster, it can be observed that $\mathrm{PM}_{10}$ and $\mathrm{PM}_{2.5}$ show the highest value of the correlation coefficient $(\rho=0.93)$. This indicates that they could share some sources and/or emission processes (Parmar et al., 2001). Due to the large number of sources emitting particulate matter in the considered area, the lack of the $\mathrm{PM}_{10}$ and $\mathrm{PM}_{2.5}$ chemical characterization, and the absence of significant correlations between $\mathrm{PM}_{10} / \mathrm{PM}_{2.5}$ and other pollutants, their main origin was not identified. Regarding the second cluster, $\mathrm{NO}_{\mathrm{x}}$ and $\mathrm{C}_{6} \mathrm{H}_{6}$ are significantly correlated with each other $(\rho=0.74)$ and with toluene ( $\rho=0.65$ ). Moreover, focusing on the third cluster, it can be observed that $\mathrm{CO}$ and THC are characterized by a correlation coefficient of 0.54 . All these compounds, although included into two separate clusters, could have originated from common sources. In fact, $\mathrm{CO}, \mathrm{NO}_{\mathrm{x}}$, VOCs and hydrocarbons as NMHCs are the main emissions of petrol and diesel-engine motor vehicles. Moreover, $\mathrm{CO}, \mathrm{NO}_{\mathrm{x}}$, VOCs and hydrocarbons, in this case as $\mathrm{CH}_{4}$, are included among the main gaseous emissions of the COVA plant (ENI, 2012). If one considers that V1 monitoring station is located at about $5 \mathrm{~m}$ from the main road connecting the industrial area with the town of Viggiano, and at about $2300 \mathrm{~m}$ from the COVA plant, this cluster could reveal the influence of both trafficand COVA-plant-related emissions on the local atmosphere.

When applying CA to the pollutant daily concentrations measured at MDB monitoring site, two clusters and four isolated variables are found (Fig. 6c). In particular, the first cluster is composed of $\mathrm{PM}_{10}, \mathrm{PM}_{2.5}$ and $\mathrm{CO}$, and the second includes $\mathrm{C}_{6} \mathrm{H}_{6}$, toluene and $\mathrm{NO}_{\mathrm{x}} . \mathrm{H}_{2} \mathrm{~S}, \mathrm{O}_{3}, \mathrm{SO}_{2}$ and THC represent the isolated variables. By considering the correlation coefficients, it can be observed that $\mathrm{PM}_{10}$ and $\mathrm{PM}_{2.5}$ are significantly correlated with each other $(\rho=0.94)$ and with CO $(\rho=0.60)$. A significant correlation between CO and PM measurements was found in areas affected by emissions coming from residential wood combustion (e.g. Bignal et al., 2008) and agricultural-burning smoke (Gonçalves et al., 2011), and/or in sites exposed to traffic emissions (Perez et al., 2004). All these types of emissions characterize the area where MDB monitoring station is located. In fact, MDB is placed in a rural area where open burning of grass and forest is a common practice used for clearing field waste in farming and ranching. Moreover, MDB is about $1400 \mathrm{~m}$ from a high-speed motorway (i.e. SS 598) characterized by a moderate volume of traffic consisting of cars and heavy vehicles. The proximity of the MDB monitoring station to the SS 598 could also justify the second cluster identified where $\mathrm{C}_{6} \mathrm{H}_{6}$ and toluene are significantly correlated with each other $(\rho=0.86)$ and with $\mathrm{NO}_{\mathrm{x}}(\rho=0.60)$. In fact, benzene and toluene are considered to be emitted from vehicle-related activity, including vehicular exhaust and gasoline evaporation (Seco et al., 2013; Wang et al., 2012), while $\mathrm{NO}_{\mathrm{x}}$ is significantly related to heavy-duty vehicle emissions (e.g. Fu et al., 2013).

Focusing on GN monitoring site, CA results point out two clusters and three isolated variables (Fig. 5d). In particular, the first cluster is composed of $\mathrm{PM}_{10}$ and $\mathrm{PM}_{2.5}$, and the 
(a)

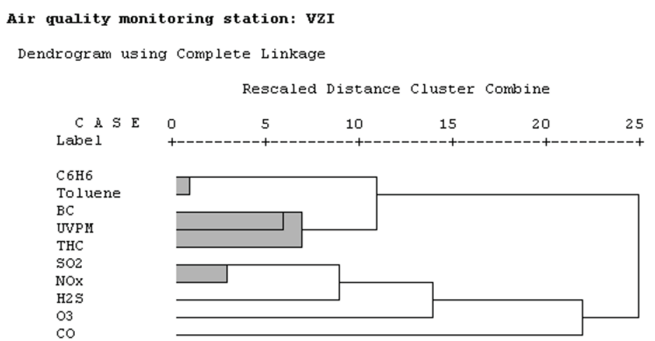

(c) Air quality monitoring station: MDB

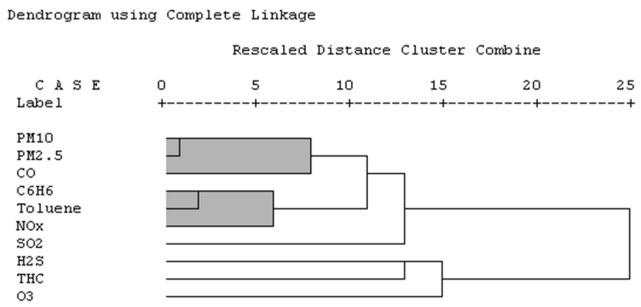

(e) Air quality monitoring station: cus

Dendrogram using Complete Linkage

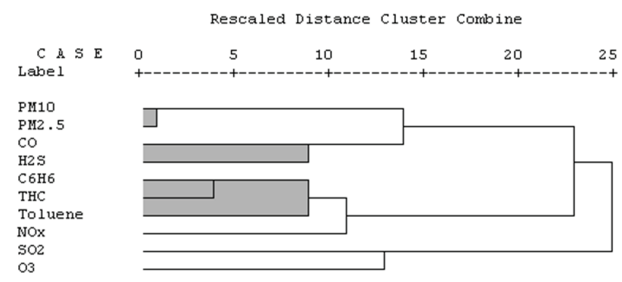

(b) Air quality monitoring station: v1

Dendrogram using Complete Linkage

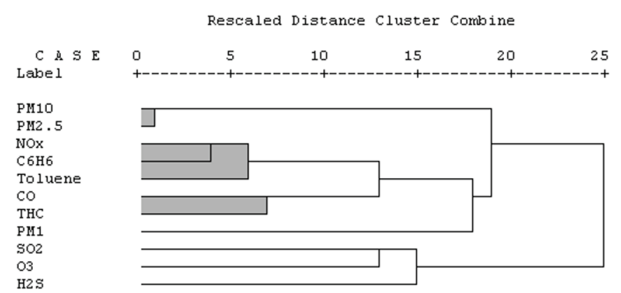

(d) Air quality monitoring station: $G$

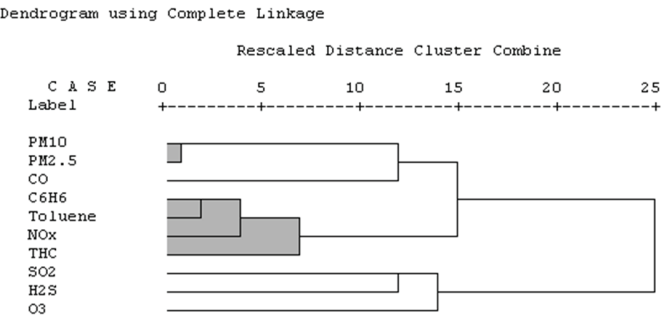

Figure 6. Dendrograms obtained by applying the furthest-neighbour clustering method to the pollutant concentration data recorded at (a) VZI monitoring site, (b) V1 monitoring site, (c) MDB monitoring site, (d) GN monitoring site and (e) CMS monitoring site. The clusters are shown in grey.

second includes $\mathrm{C}_{6} \mathrm{H}_{6}$, toluene, $\mathrm{NO}_{\mathrm{x}}$ and THC. $\mathrm{H}_{2} \mathrm{~S}, \mathrm{O}_{3}$ and $\mathrm{SO}_{2}$ represent the isolated variables. In particular, $\mathrm{PM}_{10}$ and $\mathrm{PM}_{2.5}$ show the highest value of the correlation coefficient ( $\rho=0.91)$, meaning that they are characterized by a similar behaviour. However no suggestion about their origin, and as a consequence no indication about the sources affecting the local air quality, is provided by $\mathrm{CA}$ in this case. Focusing on the second cluster, it can be observed that $\mathrm{C}_{6} \mathrm{H}_{6}$ and toluene are significantly correlated with each other $(\rho=0.81)$ and with $\mathrm{NO}_{\mathbf{x}}(\rho=0.74)$. Then, this group correlates with THC ( $\rho=0.53$ ). As found for V1 monitoring station, these correlations highlight the traffic- and COVA-plant-related contributions that can be justified if it is considered that GN monitoring station is located in the suburbs of the town of Grumento, where a contribution deriving from traffic is expected and that GN is about $2800 \mathrm{~m}$ from the COVA plant.

When applying CA to the pollutant daily concentrations measured at CMS monitoring site, three clusters and three isolated variables are found (Fig. 6e). In particular, the first cluster is composed of $\mathrm{PM}_{10}$ and $\mathrm{PM}_{2.5}$; the second includes
$\mathrm{C}_{6} \mathrm{H}_{6}$, THC and toluene; and the third is represented by $\mathrm{CO}$ and $\mathrm{H}_{2} \mathrm{~S} . \mathrm{NO}_{\mathrm{x}}, \mathrm{SO}_{2}$ and $\mathrm{O}_{3}$ represent the isolated variables. By considering the correlation coefficients between the variables included in each cluster, it can be observed that $\mathrm{PM}_{10}$ and $\mathrm{PM}_{2.5}$ show the highest value of the correlation coefficient $(\rho=0.97)$, but CA does not provide any suggestion about their origin in this case either. Regarding the second cluster, $\mathrm{C}_{6} \mathrm{H}_{6}$ and THC are significantly correlated with each other $(\rho=0.75)$ and with toluene $(\rho=0.48)$. As found for V1 and GN monitoring stations, these correlations could be attributed to COVA-plant-related contributions. Finally, focusing on the third cluster, it can be observed that $\mathrm{CO}$ and $\mathrm{H}_{2} \mathrm{~S}$ are correlated with each other $(\rho=0.48)$. This cluster very likely reveals the impact of the COVA emissions on the local air quality, probably deriving from the incomplete combustion of the natural gas in the plant's system of torches.

\subsection{Data spatial variance}

In order to better assess the pollutant concentration spatial variability, a coefficient of divergence (COD) and the 
Pearson correlation coefficients $(\rho)$ were calculated between the pollutant concentrations measured at the five air quality stations.

Regarding the COD, it was calculated for each parameter and for each pair of stations to obtain an estimate of the degree of the data set uniformity following Eq. (1):

$\operatorname{COD} j, k=\sqrt{\frac{1}{p} \sum_{i=1}^{p}\left[\left(x_{i j}-x_{i k}\right) /\left(x_{i j}+x_{i k}\right)\right]^{2}}$,

where $x$ represents the daily concentrations and the $i, j$ and $k$ indexes refer respectively to the sampling day and to the two sampling stations (Wongphatarakul et al., 1998). The CODs can vary from 0 (maximum degree of homogeneity) to 1 (minimum degree of homogeneity) for the considered pollutant concentrations measured at each pair of sampling sites.

COD and $\rho$ values are reported in Tables 4 and 5, respectively.

Substantial homogeneity was observed for $\mathrm{CH}_{4}$ and $\mathrm{O}_{3}$ when they were compared to the other pollutants. In fact, they show low values of CODs and relatively high $\rho$ values very likely due to their longer residence times in the atmosphere with respect to the other pollutants. This peculiar feature allowed for a more uniform distribution of the pollutants over the entire area, which was also favoured by frequent high-pressure conditions characterizing the considered period (see Fig. 2).

Focusing on the comparison between the $\mathrm{CH}_{4}$ and $\mathrm{O}_{3}$ concentrations measured at the five air quality stations, the higher COD and the lower $\rho$ values found when the coupling with the MDB station was considered confirm the peculiarity of this site for $\mathrm{CH}_{4}$ production, as already reported in Sect. 3.1. Then, looking at the $\mathrm{O}_{3} \rho$ values, the highest values were found when VZI and MDB stations were excluded from the coupling, implying that these two stations are different from the others with regard to ozone. This is in accordance with the lower mean values of $\mathrm{O}_{3}$ found at VZI and MDB stations (see Table 3), where at the same time high concentration values of both $\mathrm{NO}_{\mathrm{x}}$ and $\mathrm{NMHCs}$, the two wellknown main ozone precursors, are found. This confirms the larger probability that ozone enhancement is detected at sites far from where it is formed through secondary processes ( $\mathrm{Li}$ et al., 2013).

Regarding $\mathrm{PM}_{10}$ and $\mathrm{PM}_{2.5}$, a comparison was possible in all cases except for VZI station, where no measurements were available for these two parameters. For the remaining stations, very low CODs and very high $\rho$ values were obtained, highlighting a spread and homogeneous diffusion of such pollutants over the study area. This could be due to common sources of these two parameters, and their uniform presence in the local atmosphere could be also associated with the prevalence of high-pressure systems over the area during the study period.
For benzene, toluene and nitrogen compounds, higher values of COD and correspondingly lower $\rho$ values were found when the coupling with VZI station was considered. This can be attributed to an additional source of such compounds other than traffic present at VZI and related to the COVA emissions as previously assessed by the CA. Looking in particular at $\mathrm{NO}_{\mathrm{x}}$, benzene and toluene, good values of $\rho$ and low values of COD were found when the other four stations were considered, suggesting a common source of traffic that is in agreement with CA results.

Regarding $\mathrm{SO}_{2}$, COD values did not show any particular trend while the lowest $\rho$ values were found when MDB station was considered. In the case of $\mathrm{H}_{2} \mathrm{~S}$, lowest $\rho$ values were found for VZI coupling, suggesting the presence of a source of this pollutant at the sampling site located close to the COVA plant. At the same time, the highest CODs correspond to the coupling with MDB station, where particularly low mean values of this parameter were registered, as reported in Table 3, probably due to the upwind position of this station with respect to the COVA (see Fig. 1 and Table 2, where prevailing wind direction is mentioned).

As to $\mathrm{CO}$, a lack of homogeneity was present for all the stations. This, in agreement with what was found by CA, reflects the presence of several different sources of $\mathrm{CO}$ in the area, including COVA emissions, traffic, and combustion processes related to agricultural activities.

Finally, when NMHCs are considered, a lack of homogeneity was present for all the stations, probably due to their short residence time in the atmosphere.

\section{Conclusions}

Daily pollutant concentrations available in the Val d'Agri area for the period 1 September-31 October 2013 were considered and analysed along with simultaneous concentration measurements of $\mathrm{PM}_{1}$ and $\mathrm{BC}$ obtained involving additional experimental facilities. In particular, the temporal and spatial variability of the pollutant concentration measurements and the intra- and inter-site correlations were investigated using multivariate statistical techniques. Preliminary indications about the source types contributing to the presence of pollutants in the local atmosphere, as well as some indications about specific areas potentially affected by hazards deriving from the COVA plant, have also been provided. Results show that the COVA plant emissions have an impact on the air quality over the entire area. These impacts have mainly been found in the area closest to the COVA plant, represented by VZI station. Moreover, the area where CMS monitoring station is located seems also to be significantly affected by the COVA-plant-related emissions. Focusing on VZI station, it can be observed that several pollutants specifically related to the combustion processes occurring in this plant (i.e. $\mathrm{NO}_{\mathrm{x}}$, benzene and toluene) show the highest concentration values and significant correlations. In particular, 
Table 4. Coefficients of divergence (CODs) calculated for each pollutant and each pair of stations. Legend: n.c. - not calculable.

\begin{tabular}{|c|c|c|c|c|c|c|c|c|c|c|}
\hline COD & $\mathrm{VZI/V1}$ & VZI/CMS & VZI/GN & VZI/MDB & V1/CMS & $\mathrm{V} 1 / \mathrm{GN}$ & V1/MDB & $\mathrm{CMS} / \mathrm{GN}$ & CMS/MDB & GN/MDB \\
\hline $\mathrm{SO}_{2}$ & 0.17 & 0.31 & 0.26 & 0.24 & 0.38 & 0.32 & 0.11 & 0.18 & 0.43 & 0.37 \\
\hline NO & 0.66 & 0.75 & 0.68 & 0.60 & 0.32 & 0.30 & 0.28 & 0.30 & 0.38 & 0.29 \\
\hline $\mathrm{NO}_{2}$ & 0.52 & 0.57 & 0.56 & 0.44 & 0.21 & 0.23 & 0.18 & 0.19 & 0.19 & 0.23 \\
\hline $\mathrm{NO}_{\mathrm{x}}$ & 0.56 & 0.63 & 0.60 & 0.49 & 0.20 & 0.19 & 0.17 & 0.16 & 0.22 & 0.21 \\
\hline $\mathrm{PM}_{10}$ & n.c. & n.c. & n.c. & n.c. & 0.10 & 0.08 & 0.16 & 0.12 & 0.10 & 0.17 \\
\hline $\mathrm{PM}_{2.5}$ & n.c. & n.c. & n.c. & n.c. & 0.16 & 0.10 & 0.16 & 0.12 & 0.24 & 0.16 \\
\hline $\mathrm{O}_{3}$ & 0.19 & 0.10 & 0.20 & 0.10 & 0.09 & 0.03 & 0.28 & 0.11 & 0.19 & 0.29 \\
\hline $\mathrm{CO}$ & 0.36 & 0.27 & 0.17 & 0.40 & 0.21 & 0.35 & 0.16 & 0.25 & 0.20 & 0.39 \\
\hline $\mathrm{C}_{6} \mathrm{H}_{6}$ & 0.46 & 0.60 & 0.67 & 0.51 & 0.19 & 0.36 & 0.13 & 0.31 & 0.18 & 0.33 \\
\hline Toluene & 0.45 & 0.60 & 0.67 & 0.50 & 0.33 & 0.43 & 0.21 & 0.24 & 0.22 & 0.32 \\
\hline $\mathrm{CH}_{4}$ & 0.03 & 0.03 & 0.02 & 0.08 & 0.01 & 0.03 & 0.11 & 0.02 & 0.10 & 0.09 \\
\hline NMHCs & 0.54 & 0.29 & 0.44 & 0.52 & 0.50 & 0.73 & 0.62 & 0.45 & 0.50 & 0.56 \\
\hline THC & 0.08 & 0.06 & 0.05 & 0.09 & 0.03 & 0.08 & 0.14 & 0.06 & 0.11 & 0.07 \\
\hline $\mathrm{H}_{2} \mathrm{~S}$ & 0.20 & 0.23 & 0.23 & 0.60 & 0.24 & 0.21 & 0.58 & 0.32 & 0.69 & 0.55 \\
\hline
\end{tabular}

Table 5. Pearson correlation coefficients $(\rho)$ calculated for each pollutant and each pair of stations. Legend: n.c. - not calculable.

\begin{tabular}{|c|c|c|c|c|c|c|c|c|c|c|}
\hline$\rho$ & VZI/V1 & VZI/CMS & VZI/GN & VZI/MDB & V1/CMS & V1/GN & V1/MDB & CMS/GN & CMS/MDB & GN/MDB \\
\hline $\mathrm{SO}_{2}$ & 0.31 & 0.29 & 0.002 & -0.26 & 0.40 & 0.50 & -0.14 & 0.4 & -0.31 & -0.22 \\
\hline $\mathrm{NO}$ & 0.04 & 0.37 & 0.15 & 0.32 & 0.37 & 0.19 & 0.27 & 0.55 & 0.41 & 0.18 \\
\hline $\mathrm{NO}_{2}$ & -0.44 & -0.22 & -0.34 & -0.20 & 0.53 & 0.54 & 0.49 & 0.60 & 0.60 & 0.71 \\
\hline $\mathrm{NO}_{\mathrm{x}}$ & -0.33 & -0.02 & -0.12 & 0.03 & 0.55 & 0.53 & 0.43 & 0.60 & 0.63 & 0.55 \\
\hline $\mathrm{PM}_{10}$ & n.c. & n.c. & n.c. & n.c. & 0.92 & 0.89 & 0.87 & 0.85 & 0.86 & 0.89 \\
\hline $\mathrm{PM}_{2.5}$ & n.c. & n.c. & n.c. & n.c. & 0.91 & 0.91 & 0.88 & 0.87 & 0.87 & 0.93 \\
\hline $\mathrm{O}_{3}$ & 0.90 & 0.95 & 0.89 & 0.93 & 0.97 & 0.98 & 0.84 & 0.96 & 0.91 & 0.85 \\
\hline $\mathrm{CO}$ & -0.08 & 0.12 & 0.19 & 0.22 & -0.07 & 0.06 & 0.02 & 0.25 & 0.59 & 0.31 \\
\hline $\mathrm{C}_{6} \mathrm{H}_{6}$ & 0.50 & 0.55 & 0.4 & 0.48 & 0.7 & 0.74 & 0.73 & 0.64 & 0.72 & 0.76 \\
\hline Toluene & -0.16 & 0.17 & -0.15 & 0.05 & 0.67 & 0.72 & 0.59 & 0.67 & 0.65 & 0.71 \\
\hline $\mathrm{CH}_{4}$ & 0.55 & 0.89 & 0.63 & 0.37 & 0.63 & 0.49 & 0.37 & 0.74 & 0.37 & 0.20 \\
\hline NMHCs & -0.39 & 0.48 & -0.54 & 0.25 & 0.11 & 0.77 & 0.22 & -0.05 & 0.54 & 0.23 \\
\hline THC & -0.38 & -0.14 & -0.42 & -0.09 & 0.62 & 0.65 & 0.53 & 0.63 & 0.39 & 0.34 \\
\hline $\mathrm{H}_{2} \mathrm{~S}$ & -0.09 & -0.19 & -0.16 & -0.2 & 0.07 & 0.12 & 0.24 & 0.12 & 0.09 & 0.15 \\
\hline
\end{tabular}

the significant correlation found between BC and UVPM content and THC (mainly consisting of $\mathrm{CH}_{4}$ ) could indicate the COVA incomplete combustion processes as a source of carbonaceous compounds in this area and highlights the role of $\mathrm{BC}$ as a vehicle for organic compounds in the environment. Regarding CMS station, the impact of the COVA emissions on the local air quality probably derives from the incomplete combustion of the natural gas in the plant's system of torches. Traffic represents an additional and important source of atmospheric pollutants over the entire area. Moreover, the contribution of emission deriving from dairy cow breeding and agriculture-related activities has been found in the area where MDB monitoring station is located. This is in fair agreement with the prevailing rural features of this area. Results also show that $\mathrm{PM}_{1}$ is not correlated with any pollutant, suggesting the need for further investigation of these parameters so as to define its main origin. Regarding the intersite variability of the pollutant concentrations, substantial homogeneity was observed for $\mathrm{CH}_{4}, \mathrm{O}_{3}, \mathrm{PM}_{10}$ and $\mathrm{PM}_{2.5}$ when they were compared to the other pollutants. This is probably due to peculiar features of these pollutants (referring to $\mathrm{CH}_{4}$ and $\mathrm{O}_{3}$ ), probable common sources (referring to $\mathrm{PM}_{10}$ and $\mathrm{PM}_{2.5}$ ) and the prevalence of high-pressure systems over the area during the study period (all pollutants). Focusing on the single air quality station, $\mathrm{COD}$ and $\rho$ values confirm the presence of an additional $\mathrm{CH}_{4}$ source in the area where MDB station is located. Moreover, a difference among the VZI and MDB stations and the remaining stations is observed if $\mathrm{O}_{3}$ is considered. Finally, remarkable differences between VZI and the other stations have been confirmed when concentration values of $\mathrm{NO}_{\mathrm{x}}$, benzene, toluene and $\mathrm{H}_{2} \mathrm{~S}$ are considered.

In conclusion, the present study preliminarily highlights that a novel approach based on the integration of routine air quality measurements, innovative experimental measurements and advanced statistical analyses is suitable to give a realistic picture of the emission features of the area and to distinguish areas mainly affected by COVA plant emissions. This methodology represents an attempt to build an 
integrated observing strategy applicable to other similar industrial sites.

Acknowledgements. This work was carried out in the framework of the research agreement between "Regione Basilicata - Osservatorio Ambientale della Val d'Agri" and "Istituto di Metodologie per l'Analisi Ambientale" of the National Research Council (IMAA-CNR). The authors are indebted to Rosa Caggiano and Giulia Pavese for helpful discussions and suggestions. The authors would like to thank the Agenzia Regionale per la Protezione dell'Ambiente (ARPA) of the Basilicata region for providing environmental data and for the logistical support in $\mathrm{BC}$ measurements operations. Moreover, authors are grateful to the "Protezione Civile Gruppo Lucano - Viggiano" for the logistical support given during the $\mathrm{PM}_{1}$ sampling campaign.

Edited by: F. Vallianatos

Reviewed by: two anonymous referees

\section{References}

Anenberg, S. C., Talgo, K., Arunachalam, S., Dolwick, P., Jang, C., and West, J. J.: Impacts of global, regional, and sectoral black carbon emission reductions on surface air quality and human mortality, Atmos. Chem. Phys., 11, 7253-7267, doi:10.5194/acp-11-7253-2011, 2011.

Baltrènas, P., Baltrènaitè, E., Šerevičienė V., and Pereira, P.: Atmospheric BTEX concentrations in the vicinity of the crude oil refinery of the Baltic region, Environ. Monit. Asses., 182, 115127, 2011.

Bignal, K. L., Langridge, S., and Zhou, J. L.: Release of polycyclic aromatic hydrocarbons, carbon monoxide and particulate matter from biomass combustion in a wood-fired boiler under varying boiler conditions, Atmos. Environ., 42, 8863-8871, 2008.

Bond, T. C., Doherty, S. J., Fahey, D. W., Forster, P. M., Berntsen, T., De Angelo, B. J., Flanner, M. G., Ghan, S., Kärcher, B., Koch, D., Kinne, S., Kondo, Y., Quinn, P. K., Sarofim, M. C., Schultz, M. G., Schulz, M., Venkataraman, C., Zhang, H., Zhang, S., Bellouin, N., Guttikunda, S. K., Hopke, P. K., Jacobson, M. Z., Kaiser, J. W., Klimont, Z., Lohmann, U., Schwarz, J. P., Shindell, D., Storelvmo, T., Warren, S. G., and Zender, C. S.: Bounding the role of black carbon in the climate system: A scientific assessment, J. Geophys. Res., 118, 5380-5552, 2013.

Butterfield, D., Beccaceci, S., Sweeney, B., Green, D., Alexander, J., and Grieve, A.: Annual Report for the UK Black Carbon Network, available at: http://uk-air.defra.gov.uk/reports/cat05/ 1009031405_2009_BC_Annual_Report_Final.pdf (last access: February 2014), 2010.

Caselli, M., De Gennaro, G., Marzocca, A., Trizio, L., and Tutino, M.: Assessment of the impact of the vehicular traffic on BTEX concentration in ring roads in urban areas of Bari (Italy), Chemosphere, 81, 306-311, 2010.

COVA plant: External Emergency Plan, available at: http://www. osservatoriovaldagri.it/ (last access: February 2014), 2009 (in Italian).
Draxler, R. R. and Rolph, G. D.: HYSPLIT (Hybrid Single-Particle Lagrangian Integrated Trajectory) model, NOAA Air Resour. Lab., Silver Spring, MD, available at: http://ready.arl.noaa.gov/ HYSPLIT.php (last access: February, 2014), 2003.

EMPA: Technischer Bericht zum Nationalen Beobachtungsnetz für Luftfremdstoffe (NABEL), Swiss Federal Laboratories for Materials Testing and Research (EMPA), Dübendorf, Switzerland, available at: http://www.empa.ch/nabel (last access: March 2013), 2010.

ENI (Ente Nazionale Idrocarburi): ENI in Basilicata, Local Report 2012, available at: http://www.eni.com/files/documenti/ eni-in-basilicata.pdf, 2012 (in Italian).

Esposito, F., Calvello, M. R., Gueguen, E., and Pavese, G.: A new algorithm for brown and black carbon identification and organic carbon detection in fine atmospheric aerosols by a multi-wavelength Aethalometer, Atmos. Meas. Tech. Discuss., 5, 1003-1027, doi:10.5194/amtd-5-1003-2012, 2012.

Fu, M., Ge, Y., Wang, X., Tana, J., Yu, L., and Liang, B.: $\mathrm{NO}_{\mathrm{x}}$ emissions from Euro IV busses with SCR systems associated with urban, suburban and freeway driving patterns, Sci. Total Environ., 452-453, 222-226, 2013.

Fujita, E. M., and Campbell, D. E.: Review of Current Air Monitoring Capabilities near Refineries in the San Francisco Bay Area, Final Report, available at: http://www.baaqmd.gov/ /media/ Files/Technical\%20Services/DRI_Final_Report_061113.ashx, last access: February, 2014.

Godoi, R. H. M., Godoi, A. F. L., Gonçalves Junior, S. J., Paralovo, S. L., Borillo, G. C., Barbosa, C. G. G., Arantes, M. G., Charello, R. C., Filho, N. A. R., Grassi, M. T., Yamamoto, C. I., PotgieterVermaake, S., Rotondo, G. G., De Waelf, K., and van Grieken, R.: Healthy environment - indoor air quality of Brazilian elementary schools nearby petrochemical industry, Sci. Total Environ., 463-464, 639-646, 2013.

Gonçalves, C., Evtyugina, M., Alves, C., Monteiro, C., Pio, C., and Tomé, M.: Organic particulate emissions from field burning of garden and agriculture residues, Atmos. Res., 101, 666-680, 2011.

Hansen, A. D. A.: The Aethalometer manual, Magee Scientific, available at: http://mageesci.com/support/downloads/ Aethalometerbook2005.07.03.pdf (last accesse: February 2014), 2005.

Hsieh, L., Yang, H., and Chen, H.: Ambient BTEX and MBTE in the neighbourhoods of different industrial parks in Southern Taiwan, J. Hazard. Mater., A128, 106-115, 2006.

Kalnay, E., Kanamitsu, M., Kistler, R., Collins, W., Deaven, D., Gandin, L., Iredell, M., Saha, S., White, G., Woollen, J., Zhu, Y., Leetmaa, A., Reynolds, R., Chelliah, M., Ebisuzaki, W., Higgins, W., Janowiak, J., Mo, K. C., Ropelewski, C., Wang, J., Jenne, R., and Joseph, D.: The NCEP/NCAR 40-year reanalysis project, B. Am. Meteorol. Soc., 77, 437-470, 1996.

Kim, D., Kumfe, B. M., Anastasio, C., Kennedy, I. M., and Young, T. M.: Environmental aging of polycyclic aromatic hydrocarbons on soot and its effect on source identification, Chemosphere, 76, 1075-1081, 2009.

Legendre, L. and Legendre, P.: Numerical Ecology, Elsevier Science Publishers, Amsterdam, 1985.

Li, Y., Lau, A. K. H., Fung, J. C. H., Ma, H., and Tse, Y.: Systematic evaluation of ozone control policies using an Ozone Apportionment method, Atmos. Environ., 76, 136-146, 2013. 
Liang, L., Lal, R., Du, Z., Wu, W., and Meng, F.: Estimation of nitrous oxide and methane emission from livestock of urban agriculture in Beijing, Agr. Ecosyst. Environ., 170, 28-35, 2013.

Lin, T.-Y., Sree, U., Tseng, S.-H., Chiu, K. H., Wu, C.-H., and Lo, J.-G.: Volatile organic compound concentrations in ambient air of Kaohsiung petroleum refinery in Taiwan, Atmos. Environ., 38, 4111-4122, 2008.

Liu, P.-W., Yao, Y.-C., Tsai, J.-H., Hsu, Y.-C., Chang, L.-P., and Chang, K.-H.: Source impacts by volatile organic compounds in an industrial city of southern Taiwan, Sci. Total Environ., 398, 154-163, 2008.

Mirante, F., Alves, C., Pio, C., Pindado, O., Perez, R., Revuelta, M. A., and Artiñano, B.: Organic composition of size segregated atmospheric particulate matter, during summer and winter sampling campaigns at representative sites in Madrid, Spain, Atmos. Res., 132-133, 345-361, 2013.

Mohiuddin, K., Strezov, V., Nelson, P. F., and Stelcer, E.: Characterisation of trace metals in atmospheric particles in the vicinity of iron and steelmaking industries in Australia, Atmos. Environ., 83, 72-79, 2014.

Nair, V. S., Solmon, F., Giorgi, F., Mariotti,L., Babu, S. S., and Moorthy, K. K.: Simulation of South Asian aerosols for regional climate studies, J. Geophys. Res., 117, D04209, doi:10.1029/2011JD016711, 2012.

Parmar, R. S., Satsangi, G. S., Kumari, M., Lakhani, A., Srivastav, S. S., and Prakash, S.: Study of size-distribution of atmospheric aerosols at Agra, Atmos. Environ., 35, 693-702, 2001.

Pavese, G., Calvello, M., and Esposito, F.: Black Carbon and organic components in the atmosphere of Southern Italy: comparing emissions from different sources and production processes of carbonaceous particles, Aerosol Air Qual. Res., 12, 1146-1156, 2012.
Perez, P., Palacios, R., and Castillo, A.: Carbon monoxide concentration forecasting in Santiago, Chile, J. Air Waste Manage., 54, 908-913, 2004.

Reche, C., Querol, X., Alastuey, A., Viana, M., Pey, J., Moreno, T., Rodríguez, S., González, Y., Fernández-Camacho, R., de la Rosa, J., Dall'Osto, M., Prévôt, A. S. H., Hueglin, C., Harrison, R. M., and Quincey, P.: New considerations for PM, Black Carbon and particle number concentration for air quality monitoring across different European cities, Atmos. Chem. Phys., 11, 6207-6227, doi:10.5194/acp-11-6207-2011, 2011.

Seco, R., Peñuelas, J., Filella, I., Llusia, J., Schallhart, S., Metzger, A., Müller, M., and Hansel, A.: Volatile organic compounds in the western Mediterranean basin: urban and rural winter measurements during the DAURE campaign, Atmos. Chem. Phys., 13, 4291-4306, doi:10.5194/acp-13-4291-2013, 2013.

Solomon, P. A., Hopke, P. K., Foines, J., and Scheffe, R.: Key scientific and policy- and health-relevant findings from the U.S. Environmental Protection Agency's Particulate Matter Supersites Program and related studies: an integration and synthesis of results, J. Air Waste Manag. Assoc., 58, S3-S92, 2008.

Trippetta, S., Caggiano, R., and Telesca, L.: Analysis of particulate matter in anthropized areas characterized by the presence of crude oil pre-treatment plants: The case study of the Agri Valley (Southern Italy), Atmos. Environ., 77, 105-116, 2013.

Van Middelaar, C. E., Dijkstra, J., Berentsen, P. B. M., and De Boer, I. J. M.: Cost-effectiveness of feeding strategies to reduce greenhouse gas emissions from dairy farming, J. Dairy Sci., 97, 2427 2439, doi:10.3168/jds.2013-7648, 2014.

Wang, Y., Ren, X., Ji, D., Zhang, J., Sun, J., and Wu, F.: Characterization of volatile organic compounds in the urban area of Beijing from 2000 to 2007, J. Environ. Sci., 24, 95-101, 2012.

Wongphatarakul, V., Friedlander, S. K., and Pinto, J. P.: A comparative study of $\mathrm{PM}_{2.5}$ ambient aerosol chemical databases, Environ. Sci. Technol., 32, 3926-3934, 1998. 